Theological Research • volume 8 (2020) - P. 69-IOO doi: https://doi.org/I0.15633/thr.4I29

\title{
Tomi Karttunen
}

https://orcid.org/0000-0003-0639-7451

University of Eastern Finland

\section{The Church Is Christ Present: Luther's Theological Realism and Dietrich Bonhoeffer's Understanding of the Church as Unity of Act and Being}

\section{Abstract}

Facing the challenge of modern individualism Dietrich Bonhoeffer (190645) corrected the contemporary interpretation of Martin Luther's theology regarding the sacramentality and communal understanding of the Church. From the perspective of philosophical theology he discussed the "transcendental" and "ontological" approaches to explicate the presence of God's revelation in the Church through word and sacraments. Ecclesially and pastorally based theology required a participatory, ecclesially oriented ontology as the basis of theological epistemology. Philosophical concepts should be adapted in a theological context to explicate and construct theological content. For Bonhoeffer the Church was the place of revelation in which the human being could understand his or her existence in relation to others and lead a "personal life." More clearly and systematically than Luther, Bonhoeffer saw the Church as the Body of Christ as the place of transformation into the shape of Christ. Every individualistic idea of the Church must be wrong. Communion, doctrine, and theology belonged together. The intentions of Luther and Bonhoeffer regarding the Church's Christological and Pneumatological foundation as a sacramental communion in the Triune God, sent into the world in shared witness and service in mission and ministry still seems to have ecumenical potential concerning for example Lutheran and Catholic understandings of Church, ministry and Eucharist. 


\section{KeYWORDS}

philosophical theology, theological ontology, theological epistemology, Martin Luther's theology, Dietrich Bonhoeffer's theology, communion ecclesiology, individualism, Protestant theology

\section{Luther's Communal Theology AND INDIVIdUAlism as a Problem of Modern Protestantism}

It has been said Dietrich Bonhoeffer (1906-45) is modern theology's most significant transmitter of Luther's legacy. ${ }^{\mathrm{I}}$ One of the areas where he corrected the contemporary interpretation of Luther's theology was the sacramentality and communal understanding of the Church. Even in his doctoral thesis, Sanctorum Communio (I927), Bonhoeffer famously formulated the Church as "Christ existing as the Church."

I Cf. L. Nessan, Bonboeffer, Dietrich, Influence on, in: Encyclopedia of Martin Luther and the Reformation, Vol. I: A-L, ed. M.A. Lamport, foreword by B. Gordon, introduction by M.E. Marty, Lanham-Boulder-New York-London 20I7, p. 83: "Bonhoeffer's entire work is punctuated by explicit references to Luther, and the substance of his theology makes him the most significant representative of Luther's legacy in the modern world." The influence of Bonhoeffer's Luther interpretation for Bonhoeffer's theology is significant and has not always received sufficient attention. However, already R. Prenter, Bonhoeffer und der junge Luther, in: Die Mündige Welt IV, Bd. I, Weissensee 1961, pp. I52-159 wrote about Bonhoeffer and the young Luther. For example D. Hampson, Christian Contradictions. The Structures of Lutheran and Catholic Thought, Cambridge 20oI, p. 9 interprets in her study that Bonhoeffer developed the theological insights of Luther in the modern context: “...no one more than he [Bonhoeffer] took up and translated Lutheran insights, expressing them in other form. I believe that reading Bonhoeffer gives one insights into Luther and not simply vice versa." To the relationship between Bonhoeffer and Luther see for example T. Karttunen, Die Polyphonie der Wirklichkeit. Erkenntnistheorie und Ontologie in der systematischen Theologie, Joensuu 2004, pp. 5I-58 and T. Karttunen, Die Luther-Lektüre Dietrich Bonhoeffers, in: Bonhoeffer und Luther. Zentrale Themen ihrer Theologie, Hrsg. K. Grünwaldt, Ch. Tietz, U. Hahn, Hannover 2007, pp. 9-31; M.P. DeJonge, Bonhoeffer's Reception of Luther, Oxford 20I7, and W. Huber, Gehorsam glauben - betend Gerechtes tun. Bonhoeffers Antworten auf Luthers Frage, "Bonhoeffer Rundbrief" Nr. II8. März 20I8, pp. 3I-47, all of whom provide also additional literature concerning the relationship of Bonhoeffer and Luther. 
This means that word, sacrament, ministry, and communion presuppose each other. The Church is not a community of abstract individuals but the Body of Christ.

In his own German ecclesiastical context of the I93os Bonhoeffer diagnosed a decline of consensus because of individualism, a loss of spiritual substance, and the Church's marginalisation. He noted that Martin Luther remained deeply aware of the origin and nature of the Church. Yet Luther's general view had begun to disintegrate after his death. By the beginning of the eighteenth century the erosion of $\mathrm{Lu}^{-}$ theran Protestantism's communal character had reached its final stage. Bonhoeffer, who was well aware of the discoveries of the Luther Renaissance, especially through his teacher Church historian Karl Holl (I866-I926), concluded: "Individualism destroyed the Protestantism of the Reformation."2

Theologically, Bonhoeffer identified the root cause of this later development in post-Luther Lutheran theology as the separation of functional and ontological Christology. This diminished the importance of ecclesiology and sacraments and complicated the understanding of how the revelation of the Triune God's was present in the Church as the Body of Christ, and thus the understanding of how God might be encountered today. Religion was something "for Sunday," a private matter. This resulted in increasing secularism and relativism in society. The Church as a cultural phenomenon wanted to be present

2 To Bonhoeffer's teacher at the Berlin theological faculty see T. Karttunen, Die Polyphonie der Wirklichkeit. Erkenntnistheorie und Ontologie in der systematischen Theologie, op. cit., pp. 38-43. Cf. D. Bonhoeffer, Ökumene, Universität, Pfarramt 1931-I932, Hrsg. E. Amelung, Ch. Strohm, München 1994 (Dietrich Bonhoeffer Werke II [= DBW II]), I45: „Luther konnte den eigentlichen Ursprung der Kirche nie vergessen, deshalb konnte er die Bindung [an den Staat] wagen. Der systematische Entwurf Luthers [war] schon mit seinem Tode auseinandergebrochen. Mit dem Anfang des I8. Jahrhunderts [war] das Ende besiegelt. Schleiermacher [wurde] der Bildner des Tempels der Humanität. Der Individualismus hat den Protestantismus der Reformation zerstört. In der nachkopernikanischen Welt tritt statt 'Glaube' das Wort religio auf (von den englischen Deisten). Es bed[eutet] die letzte, feinste der Möglichkeiten des Menschen. Der Mensch [wird] als Gott verwandt entdeckt. Die Reformation wird als die Entdeckung dieses Menschen betrachtet." "Individualism" seems to refer to the absolute autonomy of the subject and the distorted Protestantism of Reformation Lutheranism in contrast to the theology of Martin Luther in his own writings. 
everywhere, but the consequence was that it was absent everywhere. The distinct identity of the transmitted message had been lost in the process of contextualisation. ${ }^{3}$

Accordingly, the most crucial challenge of theology for Bonhoeffer was to define "the place of the Church as the place of God in the world." ${ }^{4}$ In contrast to the more individualistic scholastic model Bonhoeffer wished to assert the Church as the basis of theology and of all dogmatic articles, as St Augustine had already done in his communion ecclesiological approach. ${ }^{5}$ Yet this understanding of the Church as the place of God should not be manifested triumphantly but in the light of the cross. The Church's strength lay only in the God of the incarnation, cross, and resurrection, which the Holy Spirit actualised. ${ }^{6}$

Triumphal new forms of the idolising of human beings were promoting nihilism in the form of modern totalitarian ideologies. This brought Bonhoeffer to posit a dialectic between person and communion beyond individualism and collectivism, rooted in faith in the revelation of the Triune God in Christ, as the core of the Church's renewal and of a theology for the world. The challenge to understand the ecclesiological dialectic of person and communion in the light of Christ's sacramental presence amidst the contemporary realities also lay behind his famous formulations of "religionless Christianity" and the "non-religious interpretation of biblical concepts."

In his doctoral thesis on Bonhoeffer's sacramental theology Gerbard Cardinal Müller (1979) summarises the basic idea behind Bonhoeffer's "secular" Christianity. Bonhoeffer pointed to the need for an empirical and sociological analysis of the Christian faith in modern western societies, while also highlighting the need for a strengthened, original, and unbiased focus on the essence and call of this faith from the centre of revelation in the turning of God to the world in Jesus Christ. ${ }^{7}$ Müller regards Bonhoeffer's understanding of sacramental communion

3 DBW II, 244-246.

4 DBW II, 244.

5 DBW II, 252. For Augustine's understanding of sociality, see, for example, Ruokanen 1993. To the background of Luther's understanding of the ontology of faith in the Augustinian tradition see the article of Ilmari Karimies in this book.

6 DBW II, 248-249.

7 G.L. Müller, Bonhoeffers Theologie der Sakramente. Frankfurter theologische Studien, Frankfurt a. M. 1979, p. 24. 
ecclesiology as convergent with the teaching of the Second Vatican Council. ${ }^{8}$

Thus, Bonhoeffer's theological contributions can be understood as an attempt to explicate the biblical and patristic vision of the Church as the presence of the Triune God in Christ and, through the Holy Spirit, in the Church. Both the apophatic and cataphatic sides of faith should be taken seriously: act and being; Pneumatology and Christology; person and community. In this he intended to encapsulate the core of Luther's reformation theology in critical distinction from the dominant contemporary cultural Protestantism. My purpose here is to analyse what this means in his philosophical theology in the light of his early academic dissertations, Sanctorum Communio (1927) and Akt und Sein (1930), and in his later concretisations of these ideas.

\section{Bonhoeffer's Critique of Philosophical Subjectivism and Objectivism}

The rise of positivistic and empirical science in the nineteenth century accompanied the anthropological turn in philosophy and the human sciences. The concept of the person became newly important under the pressure of mechanistic and deterministic thought. Bonhoeffer was aware of the relevance of this discussion, but also of the danger of narrow, anthropocentric thinking. ${ }^{9}$

8 G.L. Müller, Bonhoeffers Theologie der Sakramente. Frankfurter theologische Studien, op. cit., p. 27. To Bonhoeffer's communion ecclesiology see also T. Karttunen, The Church for Others: Dietrich Bonhoeffer's Pioneering Ecumenical Vision, "The Seminary Ridge Review" Autumn 2010, pp. 8I-98 and T. Karttunen, The Church as a Person-community in the Theologies of John D. Zizioulas and D. Bonhoeffer, FS for Prof. Dr Matti Kotiranta. Luther-Agricola-society, Helsinki 2018.

9 D. Bonhoeffer, Sanctorum Communio. Eine dogmatische Untersuchung zur Soziologie der Kirche, Hrsg. J. von Soosten, München 1986 (Dietrich Bonhoeffer Werke I [= DBW I]), 19-29. Cf. D. Bonhoeffer, Schöpfung und Fall. Theologische Auslegung von Genesis ${ }_{I-3}$, Hrsg. M. Rüter, I. Tödt, München I989 (Dietrich Bonhoeffer Werke 3 [= DBW 3]), 7r: "Der Mensch, den Gott nach seinem Ebenbilde, d.h. in Freiheit geschaffen hat, ist der Mensch, der aus Erde genommen ist. Stärker konnte selbst Darwin und Feuerbach nicht reden, als hier geredet ist. Aus einem Stück Erde stammt der Mensch. Seine Verbundenheit mit der Erde gehört zu seinem Wesen”. Cf. also 
Classical philosophy took the object's presence in the sensing and knowing intellect as the starting point of knowledge. In Aristotelian realism the realia are primary in relation to the individual. The collective is accordingly primary in relation to the individual person. Bonhoeffer saw the concept of God as a-personal in Aristotle's philosophy. In stoicism a person's essence lies in their ethical and rational being, which likewise overrules their individuality. However, in contrast with the collective Aristotelian model stoicism sees the person as one of their kind: something closed, ready, the last one. In this framework social philosophy is understood as the mutual relations of similar ethical persons. In Epicurean philosophy each individual is separated from others through the individual desire they seek to pursue. ${ }^{\text {IO }}$

After the epistemological turn by Descartes Kant built an epistemological concept of the person. In the synthesis of transcendental apperception, both the I-Thou relation and the opposite of subject and object are overcome in the higher unity of the spirit in intellectual perception. In this generalising theoretical approach, which neglects the individual's concrete reality, Bonhoeffer saw essential similarities between the Aristotelian and the Kantian or German idealistic approach, whose basis was the spirit of immanence. ${ }^{\text {II }}$

However, Bonhoeffer recognised good attempts to overcome the abstract and idealistic philosophical approach in the existential and personalist philosophical turn. Heidegger brought the existential

P.H. Jørgensen, Die Bedeutung des Subjekt-Objektverhältnisses für die Theologie. Der Theo-onto-logische Konflikt mit der Existenzphilosophie. Wissenschafiche Beiträge zur kirchlichevangelischen Lehre, Hamburg 1967, p. 435 who concludes in the light of Bonhoeffer's theology: "Gottes Für-uns-sein muss sich theologisch auf Gottes Proseität gründen, dagegen nicht auf eine exklusive anthropozentrische Promeität... Hier fehlt nicht nur der universalistische Aspekt, sondern auch der soziale... Summa Summarum des hier von der Externität Ausgeführten und des von der Existenztheologie als verketzertes subjekt-objekt Verworfenen ist also mit Bonhoeffers Worten: ,Der Glaube weiss die Offenbarung als unabhängig von sich.' ,Christus ,ist' nur ,im Glauben“ und ,ist' doch Herr meines Glaubens. Er ist schlechhinniges Aussen meiner Existenz, und gerade darum trifft er sie, gibt er sich ihr zu erkennen." Cf. D. Bonhoeffer, Akt und Sein. Transzendentalphilosophie und Ontologie in der systematischen Theologie, Hrsg. H.-R. Reuter, München 1988 (Dietrich Bonhoeffer Werke 2 [= DBW 2]), 96; Io7.

IO $\mathrm{DBW}$ I, 19-22.
II $\mathrm{DBW}$ I, 22-23. 
sphere into the discussion, but also ultimately the Dasein's self-understanding comes purely from an immanent perspective, leaving no room for a transcendent God and his revelation. Likewise, personalist philosophy, with its "Thou-I" distinction, absolutised the other in a way which allowed no room for God's revelation ab extra. However, Bonhoeffer considered it useful to analyse philosophical, sociological, and other scientific conceptions and to bring them into dialogue with the theological and revelatory intentions, albeit even in the most critical philosophy the human being tried to understand him of herself from him or herself. ${ }^{\mathrm{I2}}$ In his second thesis, Act and Being: Transcendental Philosophy and Ontology in Systematic Theology (1930), Bonhoeffer discussed the "transcendental" and "ontological" approaches to explicate the presence of God's revelation in the Church through word and sacraments. ${ }^{\mathrm{I} 3}$

I2 DBW 2, 74: "Dies ,sich nicht Wahrheit geben können' ist nie mögliche Erkenntnis einer systematischen Metaphysik; denn schon diese Erkenntnis würde eine Sich-in-Wahrheit-stellen bedeuten. Sie ist aber auch keine Möglichkeit einer ,kritischen Philosophie', eine Philosophie, die das von sich erwartete, wäre in höchsten Maße unkritisch. Das Denken vermag ebensowenig das cor curvum in se aus sich zu befreien wie das gute Werk.” Cf. P.H. Jørgensen, Die Bedeutung des Subjekt-Objektverhältnisses für die Theologie, op. cit., p. 4I9 on Bonhoeffer's thinking in Akt und Sein: "Es gibt für die Philosophie keine Möglichkeit, eine ,Ontologie Gottes' zu schreiben.” Cf. also G. Maspero in his article in this book about the roots of theological ontology: "It can be shown that the theological work of the Greek Fathers of the Church was accompanied and consisted of a real reshaping of ontology in the light of Christian Revelation.” To a comparison between the ecclesiologies of Bonhoeffer and John D. Zizioulas from this perspective see T. Karttunen, The Church as a Person-community in the Theologies of John D. Zizioulas and D. Bonhoeffer, op. cit. Olli-Pekka Vainio argues in his article in this book that Aquinas and Luther seem to share a similar "metatheological stance" when dealing with the Trinity: "the nature of the divine revelation informs the nature of metaphysics, not vice versa."

I3 For Bonhoeffer's discussion with contemporary philosophy and sociology see, for example, T. Karttunen, Die Polyphonie der Wirklichkeit. Erkenntnistheorie und Ontologie in der systematischen Theologie, op. cit., pp. 66-I20. 


\section{3. "Genuine Transcendentalism" as a Critique of a Pure Relational Approach}

Bonhoeffer maintained that a "genuine transcendental" approach showed that human thought was related to the "transcendent" being, but that it did not pretend to attain that reality in its own wisdom and power. ${ }^{14}$ Christian faith was not created psychologically, but through God's word and sacraments. God was a sovereign agent, but a human being ought also to be the subject of his or her knowledge of God. The key question was how faith as a gift of God and as a human act were epistemologically interrelated: grace and religion; revelation and history. ${ }^{15}$ Luther, for example, appears to offer only some preliminary thoughts concerning the relationship between being and consciousness. Among Finnish Luther researchers Risto Saarinen has suggested that more answers to this question will be obtained from a further systematic and constructive development of Luther's thought, which Bonhoeffer also intended. ${ }^{16}$

The reality of the divine revelation could not be isolated within a rational and idealistic thought model, an autonomous system excluding any external interference. This would not be a communicative and incarnational approach. Bonhoeffer regarded Hegel's conceptual realism as a warning example of this kind of "gnosis." In emphasising the apophatic element of faith Bonhoeffer concluded that a "genuine," perfect system is only an eschatological possibility. Faith was basically an existential relationship with Christ, which Bonhoeffer called an $a c-$ tus directus. However, he did not wish to reduce faith to the existential dimension, because God's revelation had a content. Ontological concepts were therefore also needed in explicating the actus reflexus, theology, and Christian dogma, or the cataphatic element of theology. ${ }^{17}$

I4 $\mathrm{DBW}_{2,2} 28$.

I5 DBW 2, 87-88; T. Karttunen, Die Polyphonie der Wirklichkeit. Erkenntnistheorie und Ontologie in der systematischen Theologie, op. cit., pp. I24-I25.

I6 R. Saarinen, Die Teilhabe an Gott bei Luther und in der finnischen Lutherforschung, in: Luther und Ontologie. Das Sein Christi im Glauben als strukturierendes Prinzip der Theologie Luthers, Vammala I993, p. I72 (Schriften der Luther-Agricola-Gesellschaft 3I).

I7 D. Bonhoeffer, Berlin 1932-1933, Hrsg. C. Nicolaisen, E.-A. Scharffenorth, München 1997 (Dietrich Bonhoeffer Werke I2 [= DBW I2]), I9I; DBW 2, 89-9I, 95-96. 
Because word and sacraments as notae ecclesiae were the channels for the transmission of revelation, the ontological quest should also be oriented towards them. If there was to be a reflection on the content of revelation, the context should be known from within. A human being must partake in the spirit-corporeal reality before he or she could reflect on his or her new being in the Church.$^{18}$ Ecclesially and pastorally based theology, which went beyond academic analysis, had its own thought model, as Luther also maintained. ${ }^{19}$ This required a participatory, ecclesially oriented ontology as the basis of theological epistemology.

\section{4. "Genuine Ontology"}

\section{as Thought Based on Being}

The concern of "genuine ontology" was to show the primary character of being in relation to consciousness, and to uncover this being. In dealing with ontology thinking and being were related, somehow making the movement of thought part of being. Bonhoeffer referred to the input of Heidegger in this respect. ${ }^{20}$

The problem of "critical ontology" in theology was to express God both as an object of knowledge and as unobjectifiable. Revelation was present in existing reality, and faith had a positive content: the presence of Christ in the Church for the congregation as the revelation of the Triune God. This knowledge should not be systematic phenomenology,

I8 DBW 2, 98-99.

I9 Cf. D. Bonhoeffer, Barcelona, Berlin, Amerika I928-I93I, Hrsg. R. Staats, H.Ch. von Hase, München 199I (Dietrich Bonhoeffer Werke ro [= DBW ıo]). For Luther's understanding of theology as a concrete science and his critique of the abstract character of scholastic theology see E. Martikainen, Doctrina. Studien zu Luthers Begriff der Lehre, Helsinki 1992 (Luther-Agricola-Gesellschaft 26).

$20 \mathrm{DBW}_{2}$, 53. Ilmari Karimies seems to imply in his article in this book that also in Luther's theology there is a convergent dialectic between act and being based on his Augustinian tradition: "The Tabernacle image also shoes how the ontological and relational aspects of the human person come together: The spirit is both an ontological reality within the person as well as the nexus through which the person turns towards God. Luther employs the same image of the Tabernacle with clear connections to its use in the Augustinian tradition in his most famous passage about the composition of the human being, found in his commentary on Magnificat (I520) [WA 7, 550, 19-552, 4]." 
but it was "itself based on and suspended in a being-already-known" ("einem Erkanntsein gründet und aufgehoben wird"). Bonhoeffer thus understood transcendence personally, as a relationship between persons. God was the "absolute person" and, as an object of faith, a "Triune person." ${ }^{2 \text { C }}$ Concerning the dialectic between actus directus and actus reAlexus, he wrote in Concerning the Christian Idea of God (1932):

The basis of all theology is the fact of the faith. Only in the act of faith as a direct act is God recognized as the reality which is beyond and outside of our thinking, or our whole existence. Theology, then, is the attempt to set forth what is already possessed in the act of faith. [...] It knows of its own insufficiency and its limitations. So it must be its highest concern to guard these limitations and to leave room for the reality of God, which can never be conceived by theological thinking. [...] Personality is free and does not enter the general laws of my thinking. God as the absolutely free personality is, therefore, absolutely transcendent. [...] [God] reveals himself in absolute self-revelation to man. [...] [I]dealistic philosophy does not take seriously the ontological category in history... [I]deas [...] cannot lead me into the situation of personal decision. [... [ The word of God spoken to me in the act of my faith in Christ is God in his revelation as the Holy Spirit [...] [E]ven the answer of man can never be more than "I believe, help thou mine unbelief."

God's revelation was present in the Church, and if a Christian theology which sought to understand the pastoral and existential meaning of revelation was to serve the mission and ministry of the Church, it should understand the being of revelation in the Church as already "being in" the Church. The existence should be affected, but the continuity of the being - revelatory presence - should also be articulated. The reality of revelation was thus "being which constitutes the being

2I DBW 2, I04. See also T. Karttunen, Die Polyphonie der Wirklichkeit. Erkenntnistheorie und Ontologie in der systematischen Theologie, op. cit., pp. I27-I28.

22 DBW Io, 425-43r. Cf. In a way which is convergent with Bonhoeffer's analysis G. Maspero points out in his article in this book that the "Finnish criticism of Hermann Lotze's Kantian presuppositions and his nominalistic understanding of grace and justification brought to an explicit rereading of ontology from a real Trinitarian perspective... Being and history appeared together in a unprecedented synthesis that revolves around relation.” 
(the existence) of human beings" (seiendes Sein selbst). This made possible the new being of Christians. This being was "the Triune divine person," Christ himself, who existed as the church-community. "Being in Christ" was therefore also "being in the Church. ${ }^{23}$ Bonhoeffer criticised Barth for his abstract and formal understanding of the freedom of God as free from us, and underlined that Luther's understanding of the real presence of Christ in the Eucharist proclaimed the presence of God, his being free for us (pro me/nobis). It was Bonhoeffer's intention to show that the freedom of God also had a content: God was present in his word in the Church..$^{24}$ "God is nearer to me than my

23 D. Bonhoeffer, Act and Being: Transcendental Philosophy and Ontology in Systematic Theology, ed. W.W. Floyd, trans. H. M. Rumscheidt, Minneapolis 1996 (Dietrich Bonhoeffer Works English 2 [= DBWE 2]), ro8 (DBW 2, I05). See also T. Karttunen, Die Polyphonie der Wirklichkeit. Erkenntnistheorie und Ontologie in der systematischen Theologie, op. cit., p. I29.

24 DBW 2, 76, footnote I B. refers to Luther: "Vgl. aber W.A. 23, I57: ,Unseres Gottes Ehre ist die, so er sich um unsertwillen aufs allertiefst heruntergibt ins Fleisch, ins Brot, in unsern Mund, Herz und Schoß und dazu um unsertwillen leidet, daß er unehrlich gehandelt wird, beide auf dem Kreuz und Altar." DBW 2, 85: "Es handelt sich doch in der Offenbarung nicht so sehr um die Freiheit Gottes jenseits ihrer, d.h. um das ewige Beisichselbstbleiben und um die Aseität Gottes, sondern vielmehr um das Aussichheraustreten Gottes in der Offenbarung, um sein gegebenes Wort, um seinen Bund, in dem er sich gebunden hat, um seine Freiheit, die gerade in dem Frei-sich-gebunden-haben an den geschichtlichen Menschen, in dem Sich-demMenschen-zur-Verfügung-geben ihren stärksten Erweis findet. Gott ist frei nicht vom Menschen, sondern für den Menschen. Christus ist das Wort der Freiheit Gottes. Gott ist da, d.h. nicht in ewiger Nichtgegenständlichkeit, sondern - mit aller Vorläufigkeit ausgedrückt - 'habbar', faßbar in seinem Wort in der Kirche. Hier tritt dem formalen ein inhaltliches Verständnis der Freiheit Gottes gegenüber. Sollte dieses sich als echtes Verständnis der Freiheit Gottes bewähren lassen, so sind wir vom reinen Aktverständnis der Offenbarung aus auf Seinsbegriffe gewiesen.” Cf. T. Mannermaa, in his article Hat Luther eine trinitarische Ontologie?, in: Luther und die trinitarische Tradition, Ratzeburg 1994, p. 45 (Veröffentlichungen der Luther-Akademie Ratzeburg 23), about the unity of act and being in Luther's theology of the word of God as presence of the Triune God: "Von diesem Seinsverständnis her, nach dem der actus producendi verbum das Sein Gottes, und in dem esse divinum ipsum verbum ist, entwirft Luther dann einen knappen Grundriß der allgemeinen Ontologie des geschaffenen Seins... Alle 
existence." ${ }^{25}$ This emphasis also opened new possibilities for Christian spirituality and a dialogical theological approach. ${ }^{26}$

It is clear here that Bonhoeffer was also using and drawing conclusions from the biblical image of the Church as the Body of Christ in his communion or eucharistic ecclesiology. This being was not only present in the form of a closed system, but as a living reality. There was no being without act, no act without being. ${ }^{27}$ Both modern subjectivism and classical objectivism should be overcome. The intention was relevantly, obediently, and authentically to proclaim the apostolic Gospel. Revelation was a reality to be actualised. The premise was that the Triune God was present in the word and sacraments for the people of God. Therefore, "the reality of the revelation is the Being itself present in the existing reality." As the absolute person, God was free and not to be understood in a reductionist way. This "genuine ontology" was

diese Seinsstufen spiegeln je auf ihre Weise das Hervorgehen des Wortes innerhalb der Heiligen Trinität wieder."

25 DBW 2, 90, footnote 2I refers to Luther M., Daß diese Wort Christi „Das ist mein Leib" noch fest stehen wider die Schwärmgeister, in: D. Martin Luthers Werke: kritische Gesamtausgabe, Weimar I90I (Weimarer Ausgabe [= WA], 23), I35. Already Prenter in his article Dietrich Bonhoeffer und Karl Barth Offenbarungspositivismus (Die Mündige Welt, Bd.3, München 1960, II-4I) paid attention to the critique of Bonhoeffer towards Barth's "philosophical transcendentalism” and sees Bonhoeffer's Lutheran approach to be more "ontological" than Barth's, whose more cognitive approach is manifested also in his criticism towards infant baptism. To the relationship between Barth and Bonhoeffer see also T. Karttunen, Die Polyphonie der Wirklichkeit. Erkenntnistheorie und Ontologie in der systematischen Theologie, op. cit., pp. 44-5I and M.P. DeJonge, Bonhoeffer's Reception of Luther, Oxford 20I7, pp. 42-76.

26 For example, K. Rosenthal, Die Überwindung des Subjekt-Objekt-Denkens als philosophisches und theologisches Problem. Göttingen 1970, p. I27 (Forschungen zur systematischen und ökumenischen Theologie 24, Hrsg. E. Schlink) refers to Heinrich Ott's analysis of Bonhoeffer's understanding of the faith as having a basically dialogical character. It does not take an axiom as its basis but traces the imprints of the revelation dialogically.

27 This dialectical understanding of the dialectic unity between act and being appears to be convergent with Olli-Pekka Vainio's conclusion in his article in this book: "[...] it seems reasonable that we cannot do neither philosophy or theology without categories like substance and relation. It is fruitless to attempt to build a strict ontological model that emphasizes just one of these." 
not a metaphysics of being, but an attempt to describe the reality of the presence of God as the Triune person. The act of revelation took place in history, but as personal revelation it was also hidden and unobjectifiable. The person of Christ was present only in the ultimate qualification of being and non-being in the proclamation of law and Gospel. ${ }^{28}$

Bonhoeffer's theological ontology deliberately distanced itself from distinct philosophical systems. Philosophical concepts were adapted in a theological context to explicate and construct theological content. ${ }^{29}$ In my doctoral thesis I describe his basic approach from the philosophical perspective as "existential social ontology." From this perspective it is one version of "relational ontology" within a theological framework. More specifically, theologically speaking, the basis seems to be God as the "Triune person." The basis of the I-Thou relation is God as the new "I" of the believer. Being in the Church and in Christ is a partaking in the life of the Triune God.

Luther also stressed that Christ was present in faith, but that the nature of his presence could not be definitively explicated. He was present in the "darkness of faith." $3^{\circ}$ Yet Luther does not represent here mere fideism or negative theology; he employed metaphors and analogies to describe his theological understanding of the ontology of the presence of Christ, inspired by the early Church concepts perichoresis, between the two natures of Christ, "deification," and "child of God," an Augustinian concept. ${ }^{3 \mathrm{I}} \mathrm{It}$ is also clear that Luther considered union with Christ (unio) and communion (communio) to be intertwined. Participation in Christ through word and sacraments was, in other words,

28 Cf. T. Karttunen, Die Polyphonie der Wirklichkeit. Erkenntnistheorie und Ontologie in der systematischen Theologie, op. cit., pp. I29-I30.

29 Cf. R. Saarinen, Die Teilhabe an Gott bei Luther und in der finnischen Lutherforschung, op. cit., pp. I70-I7I for the theological use of the terms "ontology" and "realontic" in Finnish Luther research.

30 R. Saarinen, Die Teilhabe an Gott bei Luther und in der finnischen Lutherforschung, op. cit., p. I3 refers here to Luther's Commentary on the Galatians: "Der Glaube rechtfertigt also, weil er diesen Schatz, den gegenwärtigen Christus nämlich, ergreift und besitzt. Auf welche Weise er aber gegenwärtig ist, kann nicht gedacht werden, weil es sich wie gesagt um Finsternis handelt" (WA 40I, 229, 22-25).

3I R. Saarinen, Die Teilhabe an Gott bei Luther und in der finnischen Lutherforschung, op. cit., pp. I73, I75-I82. 
a sharing in the communion of saints (communio sanctorum), the Body of Christ. ${ }^{22}$

\section{The Being of the “Triune Person” in Existing Reality: ANALOGIA RELATIONIS}

For Bonhoeffer the creation of the human being in the image of God meant that the human being was free. This freedom was not a possession of the person for him or herself. It was a relationship. To be free was to be "free for the other," because the other had bound him or herself to me. Based on this Bonhoeffer rejected every "substantial" or "individualistic" understanding of the concept of freedom. Freedom "happened" to me through the other. Bonhoeffer saw this as the core of the Gospel, and returned to the basic ideas of his thesis in Schöpfung und Fall (1933):

[...] it is the message of the gospel itself, that God's freedom has bound itself to us, that God's free grace becomes real with us alone, that God wills not to be free for God's self, but for the humankind. Because God in Christ is free for the humankind, because God does not keep God's freedom to God's self, we can think of freedom only as "being free for"... For us in the middle who exist through Christ and who know what it means to be human through Christ's resurrection, the fact that God is free means nothing else that that we are free for God. The freedom of the Creator demonstrates itself by allowing us to be free, free for the Creator. That, however, means nothing else that that the Creator's image is created on earth. The paradox of created freedom remains undiminished. Indeed it needs to be expressed as sharply as possible. Created freedom then means [...] that God's self enters into God's creation. [...] Humankind differs from the other creatures in that God is in humankind as the very image of God in which the free Creator looks upon the Creator's own self. This is what the older dogmatic

32 S. Peura, The Church as Spiritual Communion in Luther, in: The Church as Communion: Lutheran Contributions to Ecclesiology, ed. H. Holze, Geneva 1997, p. I20; Communion in Growth, art. I7. See also J. Lutz, Unio und communio: zum Verbältnis von Rechtfertigungslehre und Kirchenverständnis bei Martin Luther. Eine Untersuchung zu ekklesiologisch relevanten Texten der Jahre 1519-1528, Paderborn 1990. 
theologians meant when they spoke of the indwelling of the Trinity in Adam. [...] The creature loves the Creator, because the Creator loves the creature. Created freedom is freedom in the Holy Spirit, but as created freedom it is humankind's own freedom. ${ }^{33}$

Following Luther, Bonhoeffer understood human freedom as partaking in the love of God. Through the life of the Triune God in the human being through faith in Christ a person was free to love. Everything was created to exist for others. The relationship with the other therefore belonged to the reality of being created a person in the image of God. However, the image of God in the human being was not analogia entis. Bonhoeffer thought this kind of analogy was inaccurate, because God existed not only immanently in himself, but also economically in the Trinity. In Christ he witnessed his "being for the human being." Bonhoeffer termed this analogy between God witnessed by Christ and a Christian as a member in the Body of Christ an analogia relationis. ${ }^{34}$ This is a key term in his Trinitarian ontology. ${ }^{35}$ It implies

33 D. Bonhoeffer, Creation and Fall. A Theological Exposition of Genesis ${ }^{-3}$, ed. J. W. de Gruchy, trans. D.S. Bax, Minneapolis 2004 (Dietrich Bonhoeffer Works English $\left._{3}\left[=\mathrm{DBWE}_{3}\right]\right), 6_{3}-64\left(\mathrm{DBW}_{3}, 59-60\right)$.

$34 \mathrm{DBW}_{3}, 60-6$ r.

35 To the discussion regarding Bonhoeffer's perichoretic understanding of a person see H.J. Abromeit, Das Geheimnis Jesu Christi. Dietrich Bonhoeffers erfahrungsbezogener Christologie (Diss I989), Neukirchen-Vluyn I991, pp. 64-Ior and Ch. Hennecke, Die Wirklichkeit der Welt erhellen. Ein ökumenischen Gespräch mit Dietrich Bonhoeffer über die ekklesiologischen Perspektiven der Moralverkündigung, Padeborn I997, p. 246. Inspired by K. Hemmerle's thoughts regarding Trinitarian ontology, Hennecke comes to the conclusion that Bonhoeffer's ontology is in the end Trinitarian ontology. To the thoughts of K. Hemmerle regarding "Trinitarian ontology," in which the analogia entis is understood as analogia trinitatis see S.-M. Wittschier, Kreuz, Trinität, Analogie. Trinitarische Ontologie unter dem Leitbild des Kreuzes, dargestellt als ästhetische Theologie, Würzburg 1987. To Luther's Trinitarian ontology see T. Mannermaa, Hat Luther eine trinitarische Ontologie?, op. cit., pp. 43-6o and S. Peura, Das Sich-Geben GottesKorreferat zu Ulrich Asendorf: Die Trinitätslehre als integrales Problem der Theologie Martin Luthers, in: Luther und die trinitarische Tradition, op. cit., pp. I3I-I46. According to Peura (p. 139): “...will ich nun thesenhaft behaupten, daß die Gegenwart Christ als Gegenwart der gesamten Trinität im glaubenden Menschen ein integrales bzw. organisierendes Prinzip der Trinitätstheologie Luthers ist. Gott nimmt uns in sein Sein und 
a kind of perichoretic thought model and his understanding of union with Christ or deification as a participation in the being of Christ for others.

The idea of a Trinitarian ontology was thus closely connected with the new creation of a person in Christ as the basis of Christian life, which was an important premise for Bonhoeffer no less than for $\mathrm{Lu}-$ ther. Bonhoeffer criticised Melanchthon's separation of the person and work of Christ in Loci Communes when he wrote: "Knowing Christ is knowing his good deeds." ${ }^{6}$ Bonhoeffer maintained that a consequence of this emphasis on the work of Christ was Christology's secondary role. Moreover, deeds could appear good when they concealed the devil. More generally, this distinction separated ontological and functional Christology.37 Bonhoeffer saw atomistic individualism and

Leben hinein und verwirklicht dadurch die Liebe in uns." In this approach there are similarities with Bonhoeffer's understanding of analogia relationis.

36 DBW I2, 289: "Melanchthons Loci von I52I heißt es: ,hoc est Christum cognoscere, beneficia eius cognoscere, non, quod isti (die Scholastiker) docent, eius naturas, modos incarnationis contueri‘. Hiermit ist die christologische Frage auf die soteriologische Frage zurückgeführt und in ihr erledigt. Das 'Wer' Christi soll hier erkannt werden allein aus seinem Werk. Das hat zur Folge, daß eine spezifische Christologie für überflüssig gelten muß. Diese Auffassung hat Epoche gemacht und ist von Schleiermacher und Ritschl durchgeführt worden. Die systematische Frage ist die: Interpretiert das Werk die Person oder interpretiert die Person das Werk? Luther sagt, alles komme bei Menschen darauf an, ob die Person gut sei. Ist die Person gut, ist auch das Werk gut, auch wenn es gar nicht so scheint. Ist das Werk gut, so läßt das in keiner Weise einen Rückshluß auf die Person zu. Das Werk kann gut aussehen und kann doch Teufelswerk sein. Es kann der Teufel in der Lichtgestalt des Engels sein.” For example, O.-P. Vainio (Justification and Participation in Christ. The Development of the Lutheran Doctrine of Justification from Luther to the Formula of Concord (1580), Leiden 2008, p. 65) conclusion is compatible with Bonhoeffer's interpretation when he states that Christology and justification is unclear in Loci I52I. "For the young Melanchthon the incarnation of Christ has a preconditioning and informative role that transmits God's salvific role rather than a specifically salvific role."Vainio sees Melancthon's older solution regarding its understanding of the effective aspect of justification as analogical to Luther's idea, but that there is an obvious ontological difference in the thought models: for Melanchthon the donum is not Christ, but the Holy Spirit.

37 For example Paul O'Callaghan underlines in his article in this book the importance of the ontological foundation of the doctrine of justification. Also S. Peura, 
damage to the understanding of the ecclesiological interconnectedness of person and communion as a consequence of this.

In his paradigmatic work In ipsa fide Christus adest (1979) Tuomo Mannermaa's analysis is that in the light of Melanchthon's later theology later post-Luther Lutheranism almost entirely interprets the inhabitation of the Trinity in the believer in such a way that only the "gifts of God" and not the Trinity are present in the faithful. Justification is thus understood entirely forensically, as a reception of the obedience and merit of Christ. ${ }^{8}$ In his criticism of the separation of Christ from his work Bonhoeffer followed Luther. This had consequences for Bonhoeffer's sacramental communion ecclesiology and the effective understanding of justification and thus of Christian ethics. In his work Nachfolge (1937) Bonhoeffer wrote accordingly:

This is the indwelling of Jesus Christ in our hearts... To describe this reality we must not speak about our Christian life but about the true life of Jesus Christ in us. "It is no longer I who live, but it is Christ who lives in me" (Gal. 2:20). The incarnate, crucified and transfigured has entered into me and lives my life. "Christ is my life" (Phil. r:2I). But together with Christ, the Father also dwells in me; and both Father and Son dwell in me through the Holy Spirit. It is indeed the holy Trinity who dwells within Christians, who permeates them and changes them into the very image of the triune God. The incarnate, the crucified and the transformed Christ takes on form in individuals because they are members of his body, the church. The church bears the incarnate,

Luthers Bedeutung für das ökumenische Gespräch aus evangelischer Sicht, in: Lutherforschung im 20. Jahrbundert: Rückblick-Bilanz-Ausblick, Hrsg. R. Vinke, Mainz 2004, p. 24I [Veröffentlichungen des Instituts für Europäische Geschichte Mainz, Abteilung für Abendländische Religionsgeschichte, Hrsg. G. May, Beiheft 62], underlines that in the Lutheran theology it is actually possible to see the connection in content between the declaration as just and making as just only then when the doctrine of justification is placed in relation to the most important basic truths of Christian faith, like the doctrine of Trinity and Christology.

38 T. Mannermaa, In ipsa fide Christus adest: Luterilaisen ja ortodoksisen kristinuskonkäsityksen leikkauspiste, Helsinki 198I, pp. I2-13, refers to Formula of Concord: Bekenntnisschriften, 785. To the view of the Mannermaa school see R. Saarinen, Justification by Faith. The View of the Mannermaa School, in: The Oxford Handbook of Martin Luther's Theology, eds. R. Kolb, I. Dinge, L. Batka, Oxford 20I4, pp. 254-263. 
crucified, and risen form of Jesus Christ. The Church is, first of all, Christ's image (Eph. 4:24; Col. 3:10), and through the church so too are all its members the image of Christ too. Within the body of Christ we have become "like Christ." 39

However, Bonhoeffer seems to have realised that his interpretation here was not unanimously accepted. Probably to avoid the negative connotations of the term "deification" for Protestant thought, Bonhoeffer reformulated the Church Father Athanasius's concept of the healing of the image and likeness of God in and through Christ - "God became man that man might become God" - as: "Human beings become human, because God became human. But human beings do not become God. They could not and do not accomplish a change in form; God changes God's form into human form in order that human beings can become, not God, but human before God." 40 This resembles the kenosis of Christ in Philippians 2:5-II..$^{4}$

However, in his doctoral thesis (1927) Bonhoeffer had already referred to Luther's formulation regarding deification based on Christ

39 D. Bonhoeffer, Discipleship, eds. G.B. Kelly, J.D. Godsey, trans. B. Green, R. Krauss, Minneapolis 20or (Dietrich Bonhoeffer Works English 4 [= DBWE 4]), 286-287; D. Bonhoeffer, Nachfolge, Hrsg. I. Tödt, H.E. Tödt, E. Feil und C. Green, München 1994 (Dietrich Bonhoeffer Werke 4 [= DBW 4]), 303. Cf. D. Hampson, Christian Contradictions. The Structures of Lutheran and Catholic Thought, Cambridge 200I, p. 23 notices that Bonhoeffer interprets the presence of Christi pro me/nobis in a similar way as Luther in his commentary on the Galatians (I535) as an "object of faith." As a proof for this understanding of the position of Luther she refers to T. Mannermaa, Theosis als Thema der Finnischen Lutherforschung, in: Luther und Theosis, Hrsg. S. Peura, A. Raunio, Helsinki I990, p. I4. Hampson thinks that the epistemology of Kierkegaard is a mediating link between Luther und Bonhoeffer. Hampson (p. 53) also thinks that the Lutheran tradition helps to understand Bonhoeffer's Christianity without religion. She seems to refer here to the justification of the ungodly in the Lutheran tradition.

40 D. Bonhoeffer, Ethik, Hrsg. M. Kuske, I. Tödt, München 1992 (Dietrich Bonhoeffer Werke 6), 83 .

4I Cf. Ari Ojell refers in his article in this book to kenosis as "the very pattern of our life, and the model of our conformity with Christ" in Luther's theology and discusses the compatibility of this understanding with the views of Gregory of Nyssa. 
taking our place so that we might also offer ourselves for the benefit of our neighbours:

But in the church-community every member is moved by the Holy Spirit; all have their divinely appointed place and their wills moved by the Spirit. Whoever lives in love is Christ in relation to neighbor but, of course, always only in this respect. "We are God through the love that makes us charitable toward our neighbor." Christians can and ought to act like Christ; they ought to bear the burdens and suffering of the neighbor. "You must open your heart to the weaknesses and needs of others as if they were your own, and offer your means as if they were theirs, just as Christ does for you in the sacrament." That is what Luther then calls "being changed into one another through love."

Bonhoeffer thus agreed with Luther in seeing Christ as the basis of faith and love and his taking of our place as the basis of our taking the place of our neighbour. More clearly and systematically than Luther, Bonhoeffer saw the Church as the Body of Christ as the place of transformation into the shape of Christ. He thus corrected the individualistic Protestant interpretation of Luther. ${ }^{43}$

42 D. Bonhoefer, Communion of Saints. A Theological Study of the Sociology of the Church, eds. C.J. Green and J. von Soosten, Fortress Press 2009 (Dietrich Bonhoeffer Works English I [= DBWE I]), I78-I79 (DBW I, II7-II8). Luther quotations: WA ı。/I, Iоо; LW II:4I2 [WA 4, 280]; LW 35:62 [WA 2, 750]; LW 35:59 [WA 2, 749]; LW 35:62 [WA 2, 750].

43 Cf. M.P. DeJonge, Bonhoeffer's Reception of Luther, op. cit., pp. 38-39 seems to interpret Bonhoeffer's understanding of the justification as "the unconditional effective word" based on Oswald Bayer's understanding of the gospel as word of promise (promissio) and as a speech act. This approach does not seem to quite satisfactorily express the participatory character of Bonhoeffer's thought, based on the sacramental presence of Christ in the Church through word and sacraments. M.P. DeJonge, Bonhoeffer's Reception of Luther, op. cit., p. 38, footnote II5 refers to Bayer's Martin Luther's Theology: A Contemporary Interpretation, trans. Th. H. Trapp, Grand Rapids 2008, pp. 52-53. 


\section{The Communion of the Church as Unity of Act and Being - Partaking in the Being of Christ for Others}

For Bonhoeffer the Church was thus the place of revelation in which the human being could understand his or her existence in relation to others and lead a "personal life" in a "fellowship of life with Christ." The Church was created through the proclamation of the "death and resurrection of Christ in the church-communion through the churchcommunion for the church-communion." Revelation must already be present for the apostolic Gospel to be proclaimed. However, the revelation was also contingent, and contingence took place here and now. The Church was in her nature an "act of revelation," in which the past became present and even future in an anamnetic way. ${ }^{45}$ The Church as "Christ existing as the Church" was a fellowship of love and Spirit as a spirit-corporeal "revelation Body of Christ." 46 As a body, present here and now, the Church was a visible Church in which the essential and the empirical Church were interconnected "like body and soul" (Luther). Bonhoeffer underlined the perichoretic presence of the Trinity in the faithful, and it was therefore only a question of perspective for him to speak of the indwelling of the Holy Spirit or the Father or Christ in the believer. ${ }^{47}$

$44 \mathrm{DBW}$, IO2.

45 DBW 2, I06-I07.

46 DBW I, 92.

47 DBW I, I50; D. Bonhoeffer, Illegale Theologenausbildung: Finkenwalde 1935-1937, Hrsg. O. Dudzus, J. Henkys in Zusammenarbeit mit S. Bobert-Stützel, D. Schulz, I. Tödt, München 1996 (Dietrich Bonhoeffer Werke I4 [= DBW I4]), 445. Cf. M. Root, Die ökumenische Bedeutung der jüngeren Entwicklungen in der lutherischen Diskussion um die Trinität, in: Luther und die trinitarische Tradition, op. cit., p. I54 analyses the perichoretic understanding of the work of the Triune God in the theologies of ecumenical Lutheran theologians like Robert Jenson and Wolfhart Pannenberg: "Die göttlichen Personen kommen in einer Weise zusammen, daß man von einem Handeln der einen Person in und durch die andere sprechen kann; die göttliche Wirkungsweise is perichoretisch... es besteht eine Analogie zwischen der Art und Weise, wie die göttlichen Personen gegenseitig ihre Wirkungsweisen durchdringen, und der Art und Weise, wie Gott innerhalb unserer Wirkungsweise handelt... Der für die neuen Diskussionen um die Trinität erforderliche Begriff von den sich gegenseitig durchdringenden 
The basis of Christ's presence in the Church and in the faithful was that he took our place. God had seen the whole of humanity in one person. ${ }^{4}$ The pro melpro nobis presence was the principle of life for the Church and for the faithful. Revelation showed that a human being was never only an individual, but always in fellowship: "in Adam" or "in Christ." According to Bonhoeffer's "Christian concept of person" a human being became a person only through the revelation in which God entered the person as their new "I." In the process, the egocentric human body - corpus Adae - was broken and the revelation body - corpus Christi - was created. ${ }^{49}$ Christ died for the Church "to lead one life, with-each-other and for-each-other." 50

The dialectic of act and being and the Church as a unity of act and being also shows that Bonhoeffer did not play "the Church of the word" and "the Church of the sacraments" against each other as in the old controversial theology. ${ }^{5}$ The interconnectedness of word and sacrament was already apparent in Bonhoeffer's early academic works, but especially in Nachfolge (1937):

[...] the body of Christ takes on visible shape not only in preaching the word, but also in the baptism and Lord's Supper... In baptism we are made members of Lord's body. In Lord's Supper we receive the gift

Kräften wird ökumenisch fruchtbarer, wenn er mit einer Ekklesiologie verknüpft wird, die die Kirche als Gemeinschaft sieht, die an der Gemeinschaft des dreieinigen Gottes teilhat... Das Leben der Kirche befindet sich nicht außerhalb des Lebens des dreieinigen Gottes, sondern es wird immer darin aufgenommen... An dieser Stelle könnte eine fruchtbare Diskussion mit der neueren finnischen Behandlung der Rechtfertigungslehre und Theosis und den hier besprochenen trinitarischen Themen einsetzen.”

48 DBW I, 75; I2I.

49 DBW I, 92.

50 DBW I, I2I.

5I Cf. J. Außermair, Konkretion und Gestalt. "Leiblichkeit" als wesentliches Element eines sakramentalen Kirchenverständnisses am Beispiel der ekklesiologischen Ansätze Paul Tillichs, Dietrich Bonhoeffers und Hans Asmussens unter ökumenischem Gesichtspunkt, Paderborn 1997, p. 386, in referring to Mödlhammer's and Müller's research, concludes that in the works of Bonhoeffer as a whole a clear convergence with Catholic ecclesiology is visible. Although he does not speak about the "sacramentality" of the Church, in almost all his writings the idea of ecclesial bodiliness, which according to Catholic understanding is essential to a sacramental understanding of the Church, can be traced. 
of bodily community (koinonia) with the body of the Lord, and through it bodily community with the members of this body. [...] The Christian community is thus essentially the community gathered to celebrate baptism and the Lord's Supper, and only then is it the community gathered to hear the word proclaimed. [...] The body of Christ becomes visible in the church-community that gathers around the Word and Sacrament. [...] According to Paul's teaching, the form of the living body of Christ is that of differentiated members (Rom. I2:5; I Cor. I2:I2ff). In this case it is impossible to make a distinction between content and form, essence and appearance. To make it would be a denial of the body of Christ, that is, of the Christ who became flesh (I John 4:3). Thus the body of Christ, claiming a space for proclamation, at the same time claims a space for the order of the church-community. The order of the church-community is of divine origin and character. [...] The offices of the church-community are "ministries" (diakonioi, I Cor. I2:5). They are appointed by God (I Cor. I2:28), by Christ (Eph. 4:II), by the Holy Spirit (Acts 20:28) within but not by the churchcommunity. Even where the church-community itself assigns offices, it does so in complete submission to the guidance of the Holy Spirit (Acts I3:2 et passim). Both office and the church-community have their origin in the Triune God. The offices exist to serve the churchcommunity, they can be justified spiritually only through this service..$^{2}$

Bonhoeffer thus underlined the visible shape of the Church in the world. ${ }^{53}$ She was no platonicidea (cf.Augsburg Confession 7). ${ }^{54}$ The Body of Christ's visibility did not lead Bonhoeffer to forget that the Church was a mixed body (corpus permixtum). Its visibility was based on word and sacraments. Yet Bonhoeffer rejected "cheap grace," which meant the forgiveness of sins as an abstract principle without the discipleship vital for the reception of "costly grace." Cheap grace regarded the

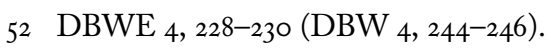

53 Cf. Bonhoeffer in Sanctorum Communio (1927): "[...] weil Christus in die Geschichte einging und so die Kirche seine Gegenwart in der Geschichte ist. Die Kirchengeschichte ist das verborgene Zentrum der Weltgeschichte, nicht die Geschichte eines Bildungsinstituts wie andere auch. Denn Kirche ist Christus als Gemeinde existierend" (DBW I, I42).

54 Cf. DBW I, I50, footnote 92: "Luther sagt: wie Leib und Seele zusammen sind" (WA VI, 297). 
incarnation as docetic and made of grace an external, abstract principle without a living relationship with Christ. 55

Alongside proclamation in word and sacraments, Bonhoeffer saw the Church's ministry as ecclesiologically constitutive. The ministries of the Church in service of the Church were of "divine origin and essence. ${ }^{56}$ Accordingly, the Church as a eucharistic community or communion had a certain constitutive structure which had a divine origin in Bonhoeffer's thought. In the background was an understanding of the Church as the Church of the Triune God.

The Church's visibility implied unity in diversity. In his doctoral thesis, Sanctorum Communio (1927), Bonhoeffer's understanding of the Church as the "unity of a communicatively structured diversity" already

$55 \mathrm{DBW}_{4}, 47$.

56 For example, G.L. Müller, Bonhoeffers Theologie der Sakramente. Frankfurter theologische Studien, op. cit., pp. 444-453 sees especially clear convergence between Bonhoeffer's and Catholic understanding of ordained ministry in three areas: I. Bonhoeffer sees the ministry as representing Christ before the congregation, transmitting the salvific apostolic sending until the end of time, and that this sending is authorised by a call, ordination, authorisation, and sending by Christ, the Saviour. From this perspective his model contains essential elements of Catholic understanding. However, how the self-effectiveness of the word and the authoritative teaching of the Church are related to each other remains a problem. 2. Bonhoeffer clearly understands vocatio and ordinatio sacramentally as effective acts. Bonhoeffer therefore understands the ordained ministry sacramentally. In the Church as sign and instrument of the transmitting of salvation in Christ the God-man is tangibly present; the Church can therefore be described as a sacrament. Yet the meaning of the apostolic succession and the inner structure of the ministry requires more elaboration. 3. There are some tensions in Bonhoeffer's critique of the Church as institution, but in underlining the pastoral motive, and especially the Church's leadership's objective authority, his intention resembles that of Catholic theology. Where unity of doctrine, the administration of the sacraments, and leadership are concerned, Bonhoeffer comes close to the essential motives of more recent Catholic theology. Müller sees in this theological thought, which is oriented towards Scripture, tradition, confession, and dogma, an ecumenical, holistic, and positive presentation of the spiritual-ecclesiastical ministry in relation to its origin in Christ and its realisation in the Church in her sending into the world, as including essential elements, guidelines, and forward-looking questions for Catholics and Protestants. 
had a clearly Trinitarian character.57 In Nachfolge (1937) Bonhoeffer was explicitly Trinitarian, and again referred to Pauline theology and to the interpretation of Galatians which - as in Luther's theology understood the presence of Christ in the faithful as the presence of the Holy Trinity in the Christian. This was important for the understanding of sacramental communion ecclesiology in Bonhoeffer's theology, which is obvious, for example, in this quotation from Nachfolge: "And where Christ lives, there the Father also lives, and both Father and Son through the Holy Ghost. The Holy Trinity himself has made his dwelling in the Christian heart, filling his whole being, and transforming him into the divine image....In the Body of Christ we are become 'like Christ." ${ }_{58}^{8}$

The Church not only "represents" Christ, but the Church "is" Christ in God's eyes. Therefore, it could be an instrument of salvation. No less than the remembering and authorising of historical reality, Christ's presence in the word of the Risen and Resurrected Lord of the Church through the Holy Spirit was important. The Spirit effected only through Christ's word - in word and sacraments - not immediately. The "word" brought to the Church an essential social and missionary dimension. Christ himself acted through the Spirit to call new members into his congregation. ${ }^{59}$

As already mentioned, the interconnectedness of person and community in Bonhoeffer's theology was a manifestation of the Church in the Holy Trinity and the New Testament image of the Church as the Body of Christ, in which members were with and for each other. ${ }^{60}$ The Church as the communion of saints was a community of faith in which

57 D. Steinfort, Communio als angemessenes Modell. Die Zukunft der Kirche nach Dietrich Bonhoeffer, in: Von der Communio zur Kommunikativen Theologie. Bernd-Jochen Hilberath zum 6o. Geburtstag, Hrsg. B. Nitsche, Berlin 2008, p. I28.

$5^{8} \mathrm{DBW}_{4}, 303$, The Cost of Discipleship, 274.

59 DBW I, roo-ior.

6o Cf. DBW I, 34: "Mein reales Verhältnis zum anderen Menschen ist orientiert an meinem Verhältnis zu Gott. Wie ich ich aber Gottes, ich' erst kenne in der Offenbarung seiner Liebe, so auch den anderen Menschen; hier hat der Kirchenbegriff einzusetzen. Dann wird es klar werden, daß christliche Person ihr eigentliches Wesen erst erreicht, wenn Gott ihr nicht als Du gegenübertriff, sondern als Ich in sie ,eingeht'. Mithin: Der Einzelne gehört mit dem anderen irgendwie wesentlich, absolut zusammen, nach dem Willen Gottes, obwohl oder gerade weil beide völlig getrennt voneinander sind.” 
the Holy Spirit awakened a personal faith which was incorporated in the congregation. The Church was the basis of faith, but simultaneously faith was the basis of the Church ${ }^{6 r}$ Communal and personal faith thus constituted a Christological and Pneumatological dialectic. "In Adam" a human being was closed within him or herself. Genuine fellowship, "being there for the others," was realised only in Christ, as a member of the Body of Christ, because "only in the Church can the revelation be understood in its existence-oriented being." ${ }_{2}$

The communion of saints functioned on the one hand through the relationship God established between the congregation and its individual members and on the other hand through those members being for the others and through the principle of taking the other's place on their behalf. Being with the others given in Christ (Miteinander) created the basis of being there for the others (Füreinander). Wherever one member of the church-community was, there the Church was also through the power of Christ and the Holy Spirit. ${ }^{63}$ Bonhoeffer shares the understanding of modern Orthodox theologians like John D. Zizioulas in stating that "only in the church-community is personal life possible." ${ }_{4}$ The Trinitarian reference also seems clear here.

In the light of current polarism it is interesting that Bonhoeffer pointed out that the unity of the Spirit in the church-community was real where the hardest external conflicts prevailed: "It can shine brighter from the struggle of wills than from unity." ${ }^{65}$ Mutual confrontation reminded us of him who above both was one and in whom both were one. Bonhoeffer pointed out that the New Testament did not say that there was "one theology and one rite, one opinion in all public and private affairs and uniform way of life, but it is said: one body and one Spirit, one Lord, one faith, one baptism, one God and Father." It was not "unity in the Spirit" but "fellowship in the Spirit." 66

In explicating how a collective person formed out of the plurality of persons without neglecting persons and personal fellowship

6I DBW I, IO2.

62 DBW 2, II2.

$63 \mathrm{DBW}$ I, II4-II7, I2O.

64 DBW I, Io2. To J. Zizioulas see, for example, Being as Communion: Studies in Personhood and the Church, Crestwood 1985.

65 DBW I, I29.

66 DBW I, I29. 
Bonhoeffer referred to Luther's explanation of Ephesians 4:3. The Holy Spirit's functioning in the Church through the word was analogous to the three basic sociological relationships which Bonhoeffer understood to be given to the Church in Christ: the plurality of the Spirit; the fellowship of the Spirit; and the unity of the Spirit. ${ }^{67}$ Unity and plurality and their dialectical unity were essential. Bonhoeffer saw exclusive commitment to Christ as making it possible to be inclusively "for others": "Unity of the Spirit, fellowship of the Spirit and plurality of the Spirit belong factually necessarily together." 68

For Bonhoeffer the consequence was that every individualistic idea of the Church must be wrong. Communion, doctrine, and theology belonged together in the Church. As he concluded in his lecture series Das Wesen der Kirche:

The correct proclamation of the word requires theology as the first extraecclesial function next to the church, the assembly of the church (council), which makes decisions about theology (heresy), and the dogma created by the council. ${ }^{69}$

\section{The Ecumenical Consequences of Sacramental Communion Ecclesiology}

The understanding of the dialectical unity of Christology and Pneumatology in the Church as "Christ present" through word and sacraments in the congregation and in the divinely instituted ministry implied a sacramental understanding of the Church as communion. The integral connection between person and community or the unity of act and being had consequences for Bonhoeffer's understanding of the relationship between the local eucharistic communion and the universal

67 DBW I, I03.

68 DBW I, I29-r30. See also T. Karttunen, Die Polyphonie der Wirklichkeit. Erkenntnistheorie und Ontologie in der systematischen Theologie, op. cit., p. I8o for the dialectic between congregation and person as the dialectic between the act and being of revelation.

69 D. Bonhoeffer, Ecumenical, Academic, and Pastoral Work: 1931-1932, eds. V.J. Barnett, M. Brocker, M.B. Lukens, trans. I. Best, et al., Minneapolis 2012 (Dietrich Bonhoeffer Works English II), 316 (DBW II, 287). 
Church. He had already dealt with this question in his doctoral thesis, describing the inner connection between a single congregation and the universal Church as the Body of Christ: “...each individual congregation is the body of Christ, and yet there is only one body; and again it is only the church-community as a whole that can actualize all the relationships within the body of Christ." ${ }^{\circ}$

Bonhoeffer's point of departure was essentially ecumenical, missionary, and diaconal, because he connected the Church as a communion of communions in and for the world with a fellowship of life and faith. However, he did not proceed from the primacy of the whole, but applied the simultaneous and dialectical relationship of person and community, or Christology and Pneumatology. Bonhoeffer emphasised that the mutual relationship of the members of the Body of Christ was not to be understood organic-bodily and functionally as parts of the functions of the same body. With reference to Luther Bonhoeffer stated: "Christ is fully present in any one person, but only all human beings together possess the whole Christ." ${ }^{\mp}$ This understanding is encapsulated in the communion ecclesiology in the Faith and Order document The Church: Towards a Common Vision (2013): "[The local Church]... is wholly Church, but it is not the whole Church." ${ }^{2}$

Concerning the universal and local communion of the churches, Bonhoeffer was an ecumenical Lutheran who emphasised that confession was at the same time absolute and relative - and again we can observe a unity of act and being here. The Bible was the norma normans as the "book of the Church." The Lutheran Church was bound to the Bible and confession and, according to Augustana XXVIII, to the divine right and duty of the bishop to proclaim the Gospel, which also included responsibility for doctrinal and disciplinary oversight. ${ }^{73}$

70 DBWE I, 225-226 (DBW I, I53).

7I DBW I, I53, footnote 99: “Holl,'Luther', S. 96 f. WA XX, 336: Fides, magna vel parva habet totum Christum. IV, $4 \mathrm{OI}$ : nunquam habet aliguis sanctorum totum Christum."

72 The Church: Towards a Common Vision. Faith and Order Paper No. 214, World Council of Churches Publications, Geneva 2013, paragraph 31.

$73 \mathrm{DBW}_{\text {I4 }}$, 705-706. Cf. DBW 3, 22: "Theologische Auslegung nimmt die Bibel als das Buch der Kirche und legt es also solches aus. Ihre Methode ist diese ihre Voraussetzung, ist fortwährendes Zurücklaufen vom Text (der mit allen Methoden philologischer und historischer Forschung zu ermitteln ist) zu dieser Voraussetzung. Das ist die Sachlichkeit der Methode der theologischen Auslegung." 
It is also noteworthy that Bonhoeffer saw matrimony as the smallest sociological unit within a congregation and thus as a "small church." Whether they realised it or wanted to, every person belonged to another, larger fellowship. Likewise, the smallest unit of the communion of saints (sanctorum communio) was outwardly focused and at the heart of the Body of Christ as a whole. A congregation was but one realisation of the Body of Christ. Bonhoeffer disagreed not only with a deductive approach from the whole to the parts but also an inductive-atomistic view in which single congregations and the body's atomistic structure were primary. ${ }^{74}$ In Christ person and community belonged together, and existed for each other.

Taken together, the theology of both Luther and Bonhoeffer has proved helpful in various ecumenical contexts. The Finnish Lutheran-Catholic theological dialogue report Communion in Growth: Declaration on the Church, Eucharist, and Ministry (2017) is a recent example of their relevance. Its presentation of sacramental communion ecclesiology is close to the intentions of Luther and Bonhoeffer regarding the Church's Christological and Pneumatological foundation as a sacramental communion in the Triune God, sent into the world in shared witness and service in mission and ministry.

\section{BibLIOGRAPHY}

Abromeit H.J., Das Geheimnis Jesu Christi. Dietrich Bonhoeffers erfahrungsbezogener Christologie (Diss 1989), Neukirchen-Vluyn 1991.

Außermair J., Konkretion und Gestalt. "Leiblichkeit" als wesentliches Element eines sakramentalen Kirchenverständnisses am Beispiel der ekklesiologischen Ansätze Paul Tillichs, Dietrich Bonhoeffers und Hans Asmussens unter ökumenischem Gesichtspunkt, Paderborn 1997.

Bayer O., Martin Luther's Theology: A Contemporary Interpretation, trans. Th.H. Trapp, Grand Rapids 2008.

Bonhoeffer D., Akt und Sein. Transzendentalphilosophie und Ontologie in der systematischen Theologie, Hrsg. H.-R. Reuter, München 1988 (Dietrich Bonhoeffer Werke 2).

$74 \mathrm{DBW}$ I, I54. 
Bonhoeffer D., Act and Being: Transcendental Philosophy and Ontology in Systematic Theology, ed. W.W. Floyd, trans. H. M. Rumscheidt, Minneapolis 1996 (Dietrich Bonhoeffer Works English 2).

Bonhoeffer D., Barcelona, Berlin, Amerika I928-I93I, Hrsg. R. Staats, H.Ch. von Hase, München 199I (Dietrich Bonhoeffer Werke ro).

Bonhoeffer D., Berlin I932-1933, Hrsg. C. Nicolaisen, E.-A. Scharffenorth, München 1997 (Dietrich Bonhoeffer Werke I2).

Bonhoeffer D., Communion of Saints. A Theological Study of the Sociology of the Church, eds. C.J. Green, J. von Soosten, Minneapolis 2009 (Dietrich Bonhoeffer Works English I).

Bonhoeffer D., Creation and Fall. A Theological Exposition of Genesis I-3, ed. J. W. de Gruchy, trans. D.S. Bax, Minneapolis 2004 (Dietrich Bonhoeffer Works English 3).

Bonhoeffer D., Discipleship, eds. G.B. Kelly, J.D. Godsey, trans. B. Green, R. Krauss, Minneapolis 200I (Dietrich Bonhoeffer Works English 4).

Bonhoeffer D., Ecumenical, Academic, and Pastoral Work: 1931-1932, eds. V.J. Barnett, M. Brocker, M.B. Lukens, trans. I. Best, et al., Minneapolis 2012 (Dietrich Bonhoeffer Works English II).

Bonhoeffer D., Ethik, Hrsg. M. Kuske, I. Tödt, München 1992 (Dietrich Bonhoeffer Werke 6).

Bonhoeffer D., Illegale Theologenausbildung: Finkenwalde 1935-1937, Hrsg. O. Dudzus, J. Henkys in Zusammenarbeit mit S. Bobert-Stützel, D. Schulz, I. Tödt, München 1996 (Dietrich Bonhoeffer Werke I4).

Bonhoeffer D., Nachfolge, Hrsg. I. Tödt, H.E. Tödt, E. Feil und C. Green, München 1994 (Dietrich Bonhoeffer Werke 4).

Bonhoeffer D., Ökumene, Universität, Pfarramt 193I-I932, Hrsg. E. Amelung, Ch. Strohm, München 1994 (Dietrich Bonhoeffer Werke II).

Bonhoeffer D., Sanctorum Communio. Eine dogmatische Untersuchung zur Soziologie der Kirche, Hrsg. J. von Soosten, München I986 (Dietrich Bonhoeffer Werke I). Bonhoeffer D., Schöpfung und Fall. Theologische Auslegung von Genesis I-3, Hrsg. M. Rüter, I. Tödt, München I989 (Dietrich Bonhoeffer Werke 3).

The Church: Towards a Common Vision. Faith and Order Paper No. 2I4, World Council of Churches Publications, Geneva 2013.

DeJonge M.P., Bonhoeffer's Reception of Luther, Oxford 2017.

Hampson D., Christian Contradictions. The Structures of Lutheran and Catholic Thought, Cambridge 200I.

Hennecke Ch., Die Wirklichkeit der Welt erhellen. Ein ökumenischen Gespräch mit Dietrich Bonhoeffer über die ekklesiologischen Perspektiven der Moralverkündigung, Paderborn 1997. 
Huber W., Gehorsam glauben - betend Gerechtes tun. Bonhoeffers Antworten auf Luthers Frage, "Bonhoeffer Rundbrief" Nr. II8. März 20I8, pp. $3 \mathrm{I}-47$.

Jørgensen P.H., Die Bedeutung des Subjekt-Objektverbältnisses für die Theologie. Der Theo-onto-logische Konflikt mit der Existenzphilosophie. Wissenschafliche Beiträge zur kirchlich-evangelischen Lehre, Hamburg Bergstedt 1967.

Karimies I., Luther's Understanding of the Ontology of Faith and the Augustinian Tradition, [draft paper].

Karttunen T., The Church as a Person-community in the Theologies of John D. Zizioulas and D. Bonhoeffer, FS for Prof. Dr Matti Kotiranta. Luther-Agricola-society, Helsinki 2018.

Karttunen T., The Church for Others: Dietrich Bonhoeffer's Pioneering Ecumenical Vision, "The Seminary Ridge Review" Autumn 20Io, pp. 8I-98.

Karttunen T., Die Luther-Lektüre Dietrich Bonhoeffers, in: Bonhoeffer und Luther. Zentrale Themen ihrer Theologie, Hrsg. K. Grünwaldt, Ch. Tietz, U. Hahn, Hannover 2007, pp. 9-32.

Karttunen T., Die Polyphonie der Wirklichkeit. Erkenntnistheorie und Ontologie in der systematischen Theologie, Joensuu 2004.

Lutz J., Unio und communio: zum Verbältnis von Rechtfertigungslehre und Kirchenverständnis bei Martin Luther. Eine Untersuchung zu ekklesiologisch relevanten Texten der Jahre 1519-1528, Paderborn 1990.

Mannermaa T., Hat Luther eine trinitarische Ontologie, in: Luther und die trinitarische Tradition, Ratzeburg 1994, pp. 43-6o (Veröffentlichungen der Luther-Akademie Ratzeburg 23).

Mannermaa T., In ipsa fide Christus adest: Luterilaisen ja ortodoksisen kristinuskonkäsityksen leikkauspiste, Helsinki i98r.

Mannermaa T., Theosis als Thema der Finnischen Lutherforschung, in: Luther und Theosis, Hrsg. S. Peura, A. Raunio, Helsinki I990, pp. II-26.

Martikainen E., Doctrina. Studien zu Luthers Begriff der Lebre, Helsinki 1992 (Luther-Agricola-Gesellschaft 26).

Müller G.L., Bonhoeffers Theologie der Sakramente. Frankfurter theologische Studien, Frankfurt a. M. 1979.

Nessan C.L., Bonhoeffer, Dietrich, Influence on, in: Encyclopedia of Martin Luther and the Reformation, Vol. I: A-L, ed. by M.A. Lamport, foreword by B. Gordon, introduction by M.E. Marty, Lanham-Boulder-New YorkLondon 20I7, pp. 8I-83.

O'Callaghan P., The Criteriological Meaning of the Lutheran Doctrine of Justification and its Ontological Underpinnings, "Theological Research" 8 (2020), pp. I3I-I5O. 
Ojell A., Trinitarian Presence and Present Christ as Righteousness and Virtue in Gregory of Nyssa's Exegesis on Beatitudes: Views for its Lutheran Ecumenical Reception, [draft paper].

Peura S., Luthers Bedeutung für das ökumenische Gespräch aus evangelischer Sicht, in: Lutherforschung im 20. Jahrbundert: Rückblick - Bilanz - Ausblick, Hrsg. R. Vinke, Mainz 2004, pp. 235-259 (Veröffentlichungen des Instituts für Europäische Geschichte Mainz, Abteilung für Abendländische Religionsgeschichte, Hrsg. G. May, Beiheft 62).

Peura S., Das Sich-Geben Gottes - Korreferat zu Ulrich Asendorf: Die Trinitätslehre als integrales Problem der Theologie Martin Luthers, in: Luther und die trinitarische Tradition, Ratzeburg 1994, pp. I3I-I46 (Veröffentlichungen der Luther-Akademie Ratzeburg 23).

Prenter R., Bonhoeffer und der junge Luther, in: Die Mündige Welt IV, Bd. I, Weissensee 196r, pp. 152-I69.

Prenter R., Dietrich Bonhoeffer und Karl Barth Offenbarungspositivismus, in: Die Mündige Welt, Bd. 3, München 1960, pp. II-4I.

Root M., Die ökumenische Bedeutung der jüngeren Entwicklungen in der lutherischen Diskussion um die Trinität, in: Luther und die trinitarische Tradition, Ratzeburg 1994, pp. 147-I59 (Veröffentlichungen der Luther-Akademie Ratzeburg 23).

Rosenthal K., Die Überwindung des Subjekt-Objekt-Denkens als philosophisches und theologisches Problem. Göttingen 1970 (Forschungen zur systematischen und ökumenischen Theologie 24, Hrsg. E. Schlink).

Ruokanen M., Theology of Social Life in Augustine's "De Civitate Die," Göttingen 1993 (Forschungen zur Kirchen- und Dogmengeschichte).

Saarinen R., Justification by Faith. The View of the Mannermaa School, in: The Oxford Handbook of Martin Luther's Theology, eds. R. Kolb, I. Dingel, L. Batka, Oxford 2014, pp. 254-263.

Saarinen R., Die Teilhabe an Gott bei Luther und in der finnischen Lutherforscbung, in: Luther und Ontologie. Das Sein Christi im Glauben als strukturierendes Prinzip der Theologie Luthers, Vammala 1993, pp. 167-182 (Schriften der Luther-Agricola-Gesellschaft 3I).

Steinfort D., Communio als angemessenes Modell. Die Zukunft der Kirche nach Dietrich Bonhoeffer, in: Von der Communio zur Kommunikativen Theologie. Bernd-Jochen Hilberath zum 6o. Geburtstag, Hrsg. B. Nitsche, Berlin 2008, pp. $125-\mathrm{I} 36$.

Vainio O.-P., Luther's Theological Ontology and the Contemporary Discussion Concerning Relational Ontology, 2020, unpublished seminar presentation. 
Wittschier S.-M., Kreuz, Trinität, Analogie. Trinitarische Ontologie unter dem Leitbild des Kreuzes, dargestellt als ästhetische Theologie, Würzburg 1987. 